\title{
THE INFLUENCE OF JOB STRESS AND COMPENSATION TO JOB SATISFACTION AT PT TRI MEGAH MAKMUR
}

\author{
I Ketut R Sudiardhita \\ Fakultas Ekonomi Universitas Negeri Jakarta \\ Email: Sudiarditha@yahoo.com \\ Fikri Haikal Baqi \\ Fakultas Ekonomi Universitas Negeri Jakarta \\ Email: fikrihaikalunj@gmail.com \\ Agung Wahyu Handaru \\ Fakultas Ekonomi Universitas Negeri Jakarta \\ Email: Agung 1178@yahoo.com
}

\begin{abstract}
The purpose of this research are: 1 ) To know description and how picture level job stress, compensation and job satisfaction at PT Tri Megah Makmur. 2) To know the influence of job stress to job satisfaction at PT Tri Megah Makmur. 3) To know the influence of compensation to job satisfaction at PT Tri Megah Makmur. 4) To know empirically the influence of job stress and compensation to job satisfaction at PT Tri Megah Makmur. 5) To know how far the contribution of job stress and compensation to job satisfaction at PT Tri Megah Makmur. This research is using descriptive and explanatory survey analysis. This research is taken to 70 sales employees at PT Tri Megah Makmur, While the data collection technique was carried out by spreading kuisioner, which are then processed using SPSS versi 21.00. The analysis shows that: 1) level of compensation and job satisfaction are on a lower level, while the job stress are high. 2) Job stress have negative effects and significantly on job satisfaction. 3) compensation have positive effect and significantly on job satisfaction. 4) job stress and compensation significantly influence on job satisfaction.
\end{abstract}

Keyword: Job Stress, Compensation, Job Satisfaction 


\section{PENDAHULUAN}

Kepuasan kerja bukanlah kata yang mudah untuk dipenuhi karena terdapat banyak faktor didalamnya yang mempengaruhi. Semakin banyak aspek-aspek dalam pekerjaan yang sesuai dengan keinginan dan harapan karyawan, semakin tinggi kepuasan kerja yang dirasakan. Setiap individu memiliki perasaan dan tingkat kepuasan yang berbeda-beda karena pada dasarnya kepuasan atau ketidakpuasan seseorang dengan pekerjaannya adalah bersifat subjektif. Karena sifatnya yang subjektif tersebut, perusahaan menjadi sulit untuk dapat membuat karyawannya memiliki perasaan puas terhadap pekerjaannya.

Tingkat ketidakpuasan kerja yang terjadi di PT. Tri Megah Makmur dapat dilihat dari tingkat kehadiran karyawan atau kemangkiran karyawan dan keterlambatan masuk karyawan yang selalu meningkat setiap bulannya yang diduga terjadi karena rutinitas pekerjaan karyawan itu sendiri dan hal tersebut yang menjadi alasan peneliti memilih PT Tri Megah Makmur sebagai objek peneliti. Berikut ini adalah data absensi ( bagian sales ) pada PT. Tri Megah Makmur

\section{Tabel 1.}

Data Absensi Karyawan PT. Tri Megah Makmur Periode Juni s/d oktober 2015

\begin{tabular}{ccccc}
\hline Bulan & Keterangan & Jumlah Karyawan & $\begin{array}{c}\text { Total Jumlah } \\
\text { Karyawan }\end{array}$ & Persentase \\
\hline Juni & Tidak hadir & 4 & 115 & $3,47 \%$ \\
\hline Juli & Tidak hadir & 6 & 115 & $5,21 \%$ \\
\hline Agustus & Tidak hadir & 10 & 112 & $8,92 \%$ \\
\hline September & Tidak hadir & 12 & 109 & $11.00 \%$ \\
\hline Oktober & Tidak hadir & 11 & 105 & $10.47 \%$ \\
\hline
\end{tabular}

Sumber : PT. Tri Megah Makmur 2016

Berdasarkan tabel 1, Dapat dilihat bahwa selalu meningkatnya ketidakhadiran karyawan tanpa alasan yang jelas setiap bulannya dari bulan juni, juli, agustus, september dan oktober 2015. Karyawan memiliki tingkat ketidakhadiran sebesar $3.47 \%, 5.21 \%, 8.92 \%, 11.00 \%$ dan $10.47 \%$. karyawan pada PT Tri Megah Makmur memiliki tingkat keterlambatan hadir dalam bekerja yang selalu 
meningkat setiap bulannya. Berikut adalah gambar data keterlambatan karyawan pada PT Tri megah Makmur dari bulan juni sampai oktober 2015 :

\section{Total Keterlambatan Karyawan}

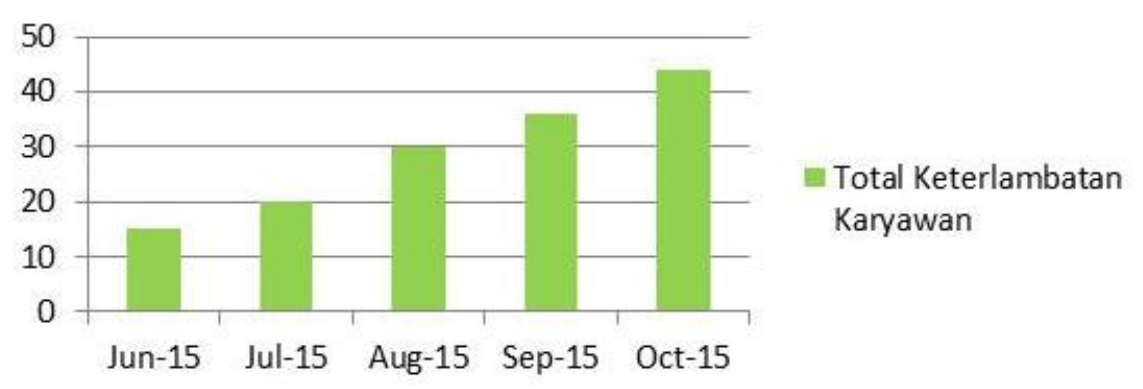

Gambar 1.

Data Keterlambatan Karyawan PT Tri Megah Makmur periode juni/oktober 2016

Berdasarkan gambar 1. dapat dilihat bahwa keterlambatan karyawan pada PT Tri Megah Makmur mengalami peningkatan setiap bulannya selama 5 bulan terakhir pada bulan juni sampai oktober 2015. Dari data diatas dapat disimpulkan bahwa karyawan pada PT Tri Megah Makmur mengalami kepuasan kerja yang rendah atau tidak terpuaskannya karyawan terhadap pekerjaannya. Hal tersebut dapat diperkuat dengan pendapat Sukarno dan Hadi (2011 : 1), menegaskan bahwa beberapa hal sebagai akibat dari tidak terpenuhinya kepuasan kerja antara lain pergantian karyawan, absensi kemangkiran dan keterlambatan karyawan.

Adapun faktor-faktor yang mempengaruhi tingkat kepuasan kerja adalah stres kerja, setelah melakukan wawancara terhadap karyawan PT.Tri Megah Makmur bahwa Stres kerja dapat di sebabkan oleh tekanan (berupa beban kerja dan tuntutan dalam bekerja), waktu kerja dan target karyawan yang harus karyawan capai dalam waktu tertentu yang sudah ditentukan oleh perusahaan. Tuntutan pekerjaan yang tinggi membuat karyawan kehilangan waktu istirahat dan bersantai, tuntutan pekerjaan berhubungan tekanan yang berasal dari waktu bekerja dan target dari perusahaan yang tinggi. Waktu bekerja di PT. Tri Megah Makmur bagian sales. Masuk jam 09.00 wib dan pulang jam 19.00 wib, tapi terkadang karyawan pada sales sering lembur dengan pulang jam 21.00 wib dan sabtu/minggu pun terkadang sering masuk tetapi tidak ada uang lembur yang di 
berikan oleh perusahaan, karyawan sering pulang melebihi jam kerja karena untuk bisa mencapai target yang tinggi sebesar Rp. 12,5 juta (kontrak) dan Rp. 15 juta (PKWT) setiap bulannya. Dengan hal tersebut, menjadi faktor karyawan mudah terkena stres kerja di karenakan karyawan harus memikirkan pencapaian target yang tinggi setiap bulannya dan para karyawan tidak mempunyai waktu refresing karena terkadang di waktu weekend masih masuk bekerja agar bisa mencapai target. Oleh karena itu karyawan yang terkena stres maka karyawan tersebut tidak akan bekerja dengan baik dan optimal dan mencerminkan kepuasan kerja yang rendah. Hal tersebut diduga stres kerja memiliki pengaruh terhadap kepuasan kerja.

Pendapat diatas didukung oleh penelitian yang dilakukan oleh Peni Tunjungsari (2011) yang menjelaskan bahwa terdapat pengaruh antara stres kerja terhadap kepuasan kerja. Diikuti dengan penelitian yang dilakukan oleh Ari Styawahyuni, Made yuniari (2013), menemukan bahwa terdapat pengaruh antara stres kerja terhadap kepuasan kerja. Dengan demikian tinggi atau rendahnya tingkat stres kerja yang dirasakan karyawan akan berdampak terhadap pada tingkat kepuasan kerja pada karyawan.

Adapun faktor-faktor lain yang mempengaruhi kepuasan kerja adalah kompensasi, kompensasi juga bisa menjadi faktor dimana karyawan rajin atau malas dalam melakukan setiap pekerjaannya, karena karyawan merasa gaji yang diterima mereka kecil dan tidak sesuai dengan upah minimum DKI jakarta 2015 yang sebesar Rp. 2.700.000 sedangkan faktanya gaji pokok di PT.Tri Megah Makmur pada bagian sales sebesar Rp. 1.700.000. Hal tersebut dapat membuat karyawan mengerjakan pekerjaannya tidak dengan sepenuh hati atau tidak dengan baik dan juga tingkat kepuasan kerja karyawan menjadi rendah, Karena mereka menganggap bahwa kompensasi yang mereka terima tidak sesuai dengan harapan yang diinginkan karyawan. Dapat diduga bahwa terdapat pengaruh antara kompensasi terhadap kepuasan kerja.

Hal diatas senada dengan penelitian yang dilakukan oleh Mardahleni (2013) menyatakan bahwa kompensasi berpengaruh terhadap kepuasan kerja. Hal serupa dengan Penelitian yang dilakukan oleh Fauzan Muttaqien (2014) yang 
menemukan bahwa kompensasi memiliki pengaruh dan signifikan terhadap kepuasan kerja. Dengan demikian semakin tinggi atau rendah tingkat kompensasi maka akan berpengaruh terhadap tinggi atau rendahnya tingkat kepuasan kerja pada karyawan PT Tri Megah Makmur.

Berdasarkan uraian diatas, peneliti tertarik untuk melakukan penelitian dengan judul : Pengaruh Stres Kerja dan Kompensasi Terhadap Kepuasan Kerja Pada PT Tri Megah Makmur.

\section{Perumusan Masalah}

1. Bagaimana deskripsi dari stres kerja, kompensasi dan kepuasan kerja pada PT Tri Megah Makmur?

2. Apakah stres kerja berpengaruh terhadap kepuasan kerja karyawan pada PT Tri Megah Makmur?

3. Apakah kompensasi berpengaruh terhadap kepuasan kerja karyawan pada PT Tri Megah Makmur?

4. Apakah stres kerja dan kompensasi memiliki pengaruh secara bersama-sama terhadap kepuasan kerja pada PT Tri Megah Makmur?

\section{Tujuan Penelitian}

1. Untuk mengetahui dan menganalisis gambaran dari stres kerja, kompensasi dan kepuasan kerja pada PT Tri Megah Makmur.

2. Untuk menguji secara empiris apakah terdapat pengaruh antara stres kerja terhadap kepuasan kerja pada PT Tri Megah Makmur.

3. Untuk menguji secara empiris apakah terdapat pengaruh antara kompensasi terhadap kepuasan kerja pada PT Tri Megah Makmur.

4. Untuk menguji secara empiris apakah terdapat pengaruh stres kerja dan kompensasi secara bersama-sama terhadap kepuasan kerja pada PT Tri megah Makmur. 


\section{KAJIAN TEORI}

\section{Kepuasan Kerja}

Menurut Robbins and Judge (2009 : 135) menjelaskan bahwa "kepuasan kerja sebagai perasaan positif tentang pekerjaan sebagai hasil evaluasi karakterkarakter pekerjaan tersebut". Senada dengan hal itu, Nelson dan Quick (2006 : 261) menyatakan "kepuasan kerja adalah suatu kondisi emosional yang positif dan menyenangkan sebagai hasil dari penilaian pekerjaan atau pengalaman pekerjaan seseorang".

Selanjutnya Siagian (2009 : 259) berpendapat "kepuasan kerja merupakan suatu cara pandang seseorang, baik yang bersifat positif maupun bersifat negatif, tentang pekerjaannya". Hal yang senada pendapat yang dilakukan oleh Umar (2009 : 36) berpendapat "kepuasan kerja adalah penilaian atau cerminan dari perasaan pekerja terhadap pekerjaannya. Hal ini tampak dalam sikap positif pekerja terhadap pekerjaannya dan segala sesuatu yang dihadapi lingkungan pekerjaannya".

Dari paparan definisi diatas maka dapat disimpulkan bahwa kepuasan kerja merupakan suatu persaan dan emosional yang positif ataupun negatif sebagai hasil dari penilaian pekerjaan, pengalaman pekerjaan dan lingkungan perkerjaan yang selalu dihadapi. Kepuasan kerja dapat diukur dengan beberapa dimensi sebagai berikut : Pekerjaan itu sendiri. Pendapatan, Kesempatan promosi, Pengawasan dan Rekan kerja.

\section{Stres Kerja}

Luthans (2012 : 29) mendefinisikan "Stres sebagai suatu tanggapan dalam menyesuaikan diri yang dipengaruhi oleh perbedaan individu dan proses psikologis, sebagai konsekuensi dari tindakan lingkungan, situasi atau peristiwa yang terlalu banyak mengadakan tuntutan psikologis dan fisik seseorang". Adapun pendapat lain yang diungkapkan oleh Mangkunegara (2011 : 4) mengatakan bahwa "Stres kerja adalah perasaan tertekan yang dialami karyawan dalam menghadapi pekerjaan. Stres kerja ini tampak dari simptom, antara lain emosi tidak stabil, perasaan tidak tenang, suka menyendiri, sulit tidur, merokok 
yang berlebihan, tidak bisa rileks, cemas, tegang, gugup, tekanan darah meningkat, dan mengalami gangguan pencernaan".

Pendapat yang hampir serupa yang dilakukan oleh Anwar Prabu (2015 : 37) "Stres kerja adalah suatu perasaan yang menekan atau rasa tertekan yang dialami karyawan dalam menghadapi pekerjaannya".

Dari paparan definisi diatas maka dapat disimpulkan bahwa Stres kerja merupakan perasaan tertekan yang dialami oleh karyawan akibat pekerjaannya. Stres kerja berdampak pada kondisi fisik dan psikis karyawan. Gangguan fisik akibat stres kerja seperti susah tidur, gangguan pencernaan, dan tekanan darah meningkat. Sedangkan gangguan psikis akibat stres kerja seperti emosi tidak stabil, perasaan tidak tenang, dan sering menyendiri.. Stres Kerja dapat diukur dengan dua dimensi sebagai berikut :

1. Organisasi

2. Personal

\section{Kompensasi}

Menurut Gomez-Mejia (2014 : 165) yang menyatakan bahwa "kompensasi merupakan bentuk penghargaan dari perusahaan kepada karyawan karena kontribusi mereka". Adapun pendapat lain yang dilakukan oleh T. Hani Handoko (2014 : 190) menyatakan bahwa "kompensasi adalah merupakan segala sesuatu yang diterima para karyawan sebagai balas jasa untuk kerja mereka”.

Adapun pendapat lain yang selaras dengan yang diatas diungkapkan oleh Garry Dessler (2014 : 190), menyatakan bahwa "kompensasi adalah semua bentuk pembayaran atau hadiah yang diberikan kepada karyawan dan muncul dari pekerjaan mereka”.

Dari penjelasan yang telah dipaparkan sebelumnya, maka dapat disimpulkan bahwa kompensasi adalah merupakan balas jasa, pengganti kontribusi, ataupun hadiah yang diberikan oleh perusahaan terhadap karyawan yang diberikan sesuai kinerja karyawan dalam melakukan pekerjaan yang diberikan oleh perusahaan, agar para karyawan dapat meningkatkan kepuasan kerja. Kompensasi dapat diukur dengan dua dimensi berikut : 
1. Langsung

2. Tidak Langsung

\section{Model Penelitian}

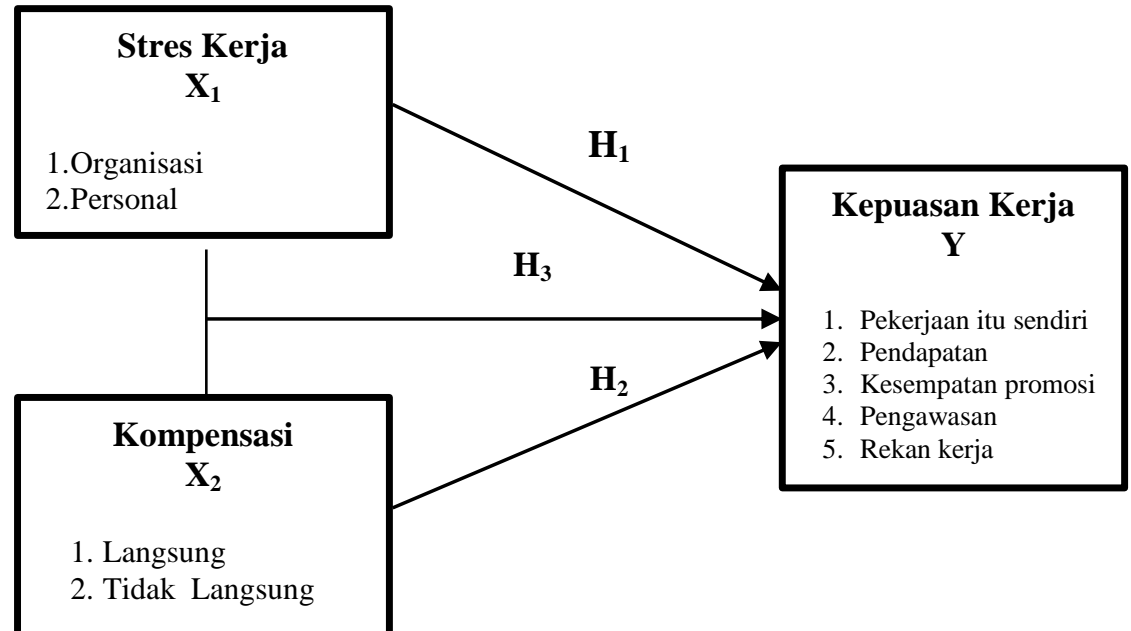

Gambar 2. Model Penelitian

Sumber : Data diolah peneliti tahun, 2016

\section{Hipotesis}

Berdasarkan kajian pustaka dan kerangka pemikiran yang telah dijelaskan sebelumnya, maka penjabaran hipotesis pada penelitian ini adalah sebagai berikut:

$\mathrm{H}_{1}$ : Stres Kerja berpengaruh terhadap Kepuasan Kerja pada PT Tri Megah Makmur.

$\mathrm{H}_{2}$ : Kompensasi berpengaruh terhadap Kepuasan Kerja pada PT Tri Megah makmur.

$\mathrm{H}_{3}$ : Stres Kerja dan kompensasi secara bersama-sama berpengaruh terhadap Kepuasan Kerja pada PT Tri Megah Makmur.

\section{METODE PENELITIAN}

Penelitian ini menggunakan metode penelitian deskriptif dan explanatory survey. Data yang digunakan dalam penelitian ini berasal dari data primer yang didapatkan melalui wawancara, observasi dan kuesioner, sedangkan data sekunder mengenai data absensi karyawan dan data keterlambatan karyawan diperoleh dari PT Tri Megah Makmur. Metode pengambilan sampel menggunakan Sample 
Random Sampling. Jumlah sampel yang digunakan dalam penelitian ini sebanyak 70 responden dari total populasi yang berjumlah 100 karyawan.

\section{Uji Instrumen}

\section{Uji Validitas}

Uji validitas digunakan untuk mengukur valid tidaknya suatu kuesioner. Instrumen yang digunakan berupa kuesioner yang diuji coba pada 33 responden yaitu karyawan PT Tri Megah Makmur. Uji validitas ini dilakukan dengan membandingkan nilai $r_{\text {hitung }}$ dan $r_{\text {tabel }}$ untuk masing-masing butir pernyataan yang ada. Jika nilai $r_{\text {hitung }}>r_{\text {tabel }}$ maka butir instrumen dikatakan Valid. Metode yang digunakan pada pengujian validitas menggunakan pendekatan korelasi product moment dengan ketentuan kevalidan instrument apabila $r_{\text {hitung }}>r_{\text {tabel }}$ pada $\mathrm{N}=70$. Sehingga didapat nilai $r_{\text {tabel }}$ sebesar 0,361 .

Tabel 2. Hasil Uji Validitas

\begin{tabular}{lccc}
\hline Variabel & $\begin{array}{c}\text { Jumlah item } \\
\text { sebelum diuji }\end{array}$ & $\begin{array}{c}\text { Jumlah item } \\
\text { tidak valid }\end{array}$ & $\begin{array}{c}\text { Jumlah item } \\
\text { valid }\end{array}$ \\
\hline Stres Kerja & 7 & 0 & 7 \\
\hline Kompensasi & 10 & 1 & 9 \\
\hline Kepuasan Kerja & 10 & 0 & 10 \\
Sumber: Data diolah peneliti tahun, 2016 & & &
\end{tabular}

Berdasarkan Tabel 2, hasil uji validitas yang dilakukan pada variabel stres kerja terhadap kepuasan kerja menghasilkan nilai $r_{\text {hitung }}$ tiap instrumennya lebih besar dari $r_{\text {tabel}}$, sehingga dapat disimpulkan bahwa seluruh butir pernyataan dalam variabel tersebut valid karena seluruh instrumen telah memenuhi syarat, yaitu nilai $r_{\text {hitung }}>r_{\text {tabel }}$ 0,361. Sedangkan untuk variabel kompensasi terdapat 1 butir pernyataan yang tidak valid karena nilai $r_{\text {hitung }}<r_{\text {tabel }}$.

\section{Uji Reliabilitas}

Uji reliabilitas dalam kuesioner penelitian ini menggunakan teknik Cronbach's Alpha, yaitu menunjukkan nilai koefisien reliabilitasnya untuk mengukur besaran nilai positif dari variabel. Jika nilai Cronbach's Alpha >0,6; maka instrumen penelitian dapat dikatakan reliabel. Hasil uji reliabilitas untuk masing-masing variabel dapat dilihat pada tabel 3 berikut ini : 
Tabel 3. Hasil Uji Reliabilitas

\begin{tabular}{ccc}
\hline Variabel & Cronbach's Alpha & Keterangan \\
\hline Stres Kerja & 0,969 & Reliabel \\
\hline Kompensasi & 0,893 & Reliabel \\
\hline Kepuasan Kerja & 0,884 & Reliabel \\
\hline
\end{tabular}

diolah peneliti tahun, 2016

Sumber: Data

Pada Tabel 3, dapat dilihat bahwa nilai Cronbach's Alpha untuk variabel stres kerja yaitu 0,969, untuk variabel kompensasi sebesar 0,893, dan kepuasan kerja 0,884. Jadi, instrumen dari ketiga variabel tersebut dinyatakan reliabel karena nilai Cronbach's Alpha > 0,6.

\section{Analisis Deskriptif}

Deskripsi data adalah hasil pengolahan data mentah variabel penelitian yang dimaksudkan untuk memberikan gambaran umum mengenai penyebaran dan distribusi data. Data merupakan hasil penelitian ini yang didapat melalui kuesioner yang disebarkan kepada sampel yaitu 70 karyawan PT Tri Megah Makmur.

\section{Uji Asumsi Klasik}

\section{Uji Normalitas}

Menurut Sugiono (2013 : 79) uji normalitas berfungsi untuk mengetahui apakah data yang diambil adalah data yang terdistribusi normal, maksud dari terdistribusi normal adalah bahwa data akan mengikuti bentuk distribusi normal dimana datanya memusat pada nilai rata-rata median. Uji normalitas pada penelitian ini menggunakan uji kolmogorov-smirnov dan dikatakan normal jika nilai residual yang terdistribusi secara normal memiliki probabilitas signifikansi > 0,05 .

\section{Uji Linearitas}

Menurut Priyatno (2010 : 73) uji linearitas bertujuan untuk mengetahui apakah dua variabel mempunyai hubungan yang linear atau tidak secara signifikan. Pengujian dapat dilakukan dengan software Statistical Product and Service Solution (SPSS), dengan menggunakan test for linearity pada taraf 
signifikasi 0.05. Kriteria dalam uji linearitas adalah dua variabel dikatakan mempunyai hubungan yang linear bila signifikasi (linearity) kurang dari 0.05 .

\section{Uji Multikolinearitas}

Menurut Umar (2008 : 80) uji multikolinearitas bertujuan untuk menguji apakah pada model regresi ditemukan adanya korelasi linear yang sempurna antar beberapa atau semua variabel bebas (independen). Mengukur multikoliniearitas dapat diketahui dengan melihat nilai Variance Inflation Factor (VIF) pada model regresi. Jika besar VIF $<5$ atau mendekati 1, maka mencerminkan tidak ada multikolinieritas.

\section{Uji Heteroskedastisitas}

Menurut Umar (2008 : 82) uji heteroskedastisitas dilakukan untuk mengetahui apakah dalam sebuah model regresi terjadi ketidaksamaan varian dari residual suatu pengamatan kepengamatan lain. Jika varian dari residual suatu pengamatan kepengamatan lain tetap, disebut homokedastisitas, sedangkan untuk varian yang berbeda disebut heteroskedastisitas. Metode yang digunakan dalam penelitian ini adalah metode uji Spearman's Rho, yaitu mengkorelasikan nilai residual (unstandardized residual) dengan masing-masing variabel independen. Jika signifikansi kurang dari 0,05, maka terjadi masalah heterokedastisitas.

\section{Uji Hipotesis}

\section{Uji Persamaan Regresi Linear Berganda}

Menurut Priyatno (2010 : 61) analisis regresi linear berganda adalah hubungan secara linear antara dua atau lebih variabel bebas dengan variabel terikat. Analisis ini untuk memprediksikan nilai dari variabel terikat apabila nilai variabel bebas mengalami kenaikan atau penurunan dan untuk mengetahui arah hubungan antara variabel bebas dengan variabel terikat, apakah masing-masing variable bebas berhubungan positif atau negatif. Model matematis persamaan regresi linear berganda dari penelitian ini adalah :

$$
\mathbf{Y}^{\prime}=\mathbf{a}+\mathbf{b}_{1} \mathbf{X}_{1}+\mathbf{b}_{2} \mathbf{X}_{2}
$$


Keterangan:

$\mathrm{Y}^{\prime} \quad$ : Variabel terikat (nilai prediksi)

a : Konstanta

$\mathrm{b}_{1}, \mathrm{~b}_{2} \quad$ : Koefisien regresi

$\mathrm{X}_{1} \quad$ : Variabel bebas

$\mathrm{X}_{2}$ : Variabel bebas

\section{Uji F}

Menurut Priyatno (2010 : 67) uji F digunakan untuk mengetahui apakah variabel bebas secara bersamaan berpengaruh atau tidak terhadap variabel terikat. Pada penelitian ini, uji F dilakukan untuk menganalisis pengaruh stres kerja $\left(\mathrm{X}_{1}\right)$ dan kompensasi $\left(\mathrm{X}_{2}\right)$ terhadap kepuasan kerja $(\mathrm{Y})$.

$\mathrm{H}_{\mathrm{o}}$ : Stres kerja dan kompensasi secara bersama-sama tidak berpengaruh terhadap kepuasan kerja.

$\mathrm{H}_{\mathrm{a}}$ : Stres kerja dan kompensasi secara bersama-sama berpengaruh terhadap kepuasan kerja.

Syarat:

1. $\mathrm{H}_{\mathrm{o}}$ diterima jika $\mathrm{F}_{\text {hitung }}<\mathrm{F}_{\text {table }}$ atau nilai signifikansi lebih besar dari 0.05.

2. $\mathrm{H}_{\mathrm{o}}$ ditolak jika $\mathrm{F}_{\text {hitung }}>\mathrm{F}_{\text {table }}$ atau nilai signifikansi lebih kecil dari 0.05.

\section{Analisis Koefisien Determinasi}

Menurut Priyatno (2010 : 66) analisis determinasi dalam regresi linear berganda digunakan untuk mengetahui persentase pengaruh sumbangan variabel bebas secara serentak terhadap variabel terikat. Koefisien ini menunjukkan seberapa besar persentase variasi variabel bebas yang digunakan dalam model mampu menjelaskan variasi variabel terikat.

\section{HASIL DAN PEMBAHASAN}

\section{Analisis Deskriptif}

Hasil analisis deskriptif untuk setiap variabel di dalam penelitian ini yaitu variabel kepuasan kerja, komitmen organisasi dan turnover intention dapat dilihat pada tabel nilai analisis deskriptif berikut :

\section{Tabel 4. Nilai Analisis Deskriptif}

\begin{tabular}{cccc}
\hline & Stres Kerja & Kompensasi & Kepuasan Kerja \\
\hline Sangat Tidak Setuju & $3,5 \%$ & $21,1 \%$ & $26,8 \%$ \\
\hline Tidak Setuju & $8,5 \%$ & $42,7 \%$ & $38,5 \%$ \\
\hline
\end{tabular}




\begin{tabular}{cccc}
\hline Kurang Setuju & $23,6 \%$ & $21,2 \%$ & $23,0 \%$ \\
\hline Setuju & $31,0 \%$ & $13,0 \%$ & $8,5 \%$ \\
\hline Sangat Setuju & $33,5 \%$ & $2,0 \%$ & $3,2 \%$ \\
\hline Sumber : Data diolah oleh penelitI, 2016 & &
\end{tabular}

Pada Tabel 4 dapat dilihat persentase jawaban yang diberikan oleh para responden yang menggambarkan setiap variabel. Pada variabel stres kerja, dapat dilihat bahwa jawaban yang diberikan responden didominasi dengan jawaban Sangat Setuju yaitu sebesar 33.5\%. Artinya, mayoritas responden mempunyai tingkat Stres kerja yang tinggi. Stres kerja yang tinggi diakibatkan karena responden merasa target yang diberikan perusahaan terlalu tinggi, beban kerja yang berat dan setiap karyawan mempunyai sifat tertutup. Hal tersebut mmbuat karyawan menjadi terbebani terhadap pekerjaanya sehingga dapat menimbulkan rasa stres kerja pada saat bekerja.

Pada variabel kompensasi, hasil persentase terbesar berasal dari jawaban Tidak Setuju yaitu sebesar $42.7 \%$. Artinya, mayoritas responden memiliki tingkat kompensasi yang rendah berdasarkan kriteria tingkat kompensasi. Kompensasi yang rendah diakibatkan oleh pendapatan yang mayoritas responden masih memiliki pendapatan dibawah standar Upah Minimum Regional (UMR) maupun standar perusahaan distributor sejenis.

Untuk variabel kepuasan kerja didominasi dengan jawaban Tidak Setuju sebesar 38,5\%. Artinya, mayoritas responden memiliki tingkat kepuasan kerja yang rendah berdasarkan kriteria tingkat kepuasan kerja. rendahnya tingkat kepuasan kerja dapat dilihat dari jawaban responden yang menyatakan tidak setuju. Di akibatkan karena responden merasa pengawasan yang diberikan oleh atasan belum sepenuhnya optimal dan menyeluruh. Seringkali atasan memberikan pengawasan secara subjektif kepada karyawannya, sehingga masih ada karyawan yang merasa tidak terbantu dan tidak diperhatikan dalam bekerja dan pendapatan yang responden dapat belum cukup untuk memenuhi kebutuhan hidup mereka, sehimgga membuat karyawan merasa tidak terpuaskan terhadap pekerjaannya. 


\section{Hasil Uji Asumsi Klasik}

\section{Uji Normalitas}

Uji normalitas yang terdistribusi secara normal memiliki probabilitas signifikansi lebih besar dari 0.05 . Hasil uji normalitas dapat dilihat pada tabel 5 :

Tabel 5.

Hasil Uji Normalitas

One-Sample Kolmogorov-Smirnov Test

\begin{tabular}{|c|c|c|c|c|}
\hline & & $\begin{array}{c}\text { Kepuasan } \\
\text { Kerja (Y) }\end{array}$ & $\begin{array}{c}\text { Stress Kerja } \\
(\mathrm{X} 1)\end{array}$ & $\begin{array}{c}\text { Kompensasi } \\
(\mathrm{X} 2)\end{array}$ \\
\hline $\mathrm{N}$ & & 70 & 70 & 70 \\
\hline \multirow{2}{*}{ Normal Parameters ${ }^{\mathrm{a}, \mathrm{b}}$} & Mean & 22.41 & 26.71 & 17.71 \\
\hline & Std. Deviation & 5.301 & 4.524 & 3.616 \\
\hline Most Extreme & Absolute & .127 & .140 & .107 \\
\hline \multirow[t]{2}{*}{ Differences } & Positive & .127 & .082 & .107 \\
\hline & Negative & -.095 & -.140 & -.082 \\
\hline Kolmogorov-Smirnov Z & & 1.066 & 1.175 & .891 \\
\hline Asymp. Sig. (2-tailed) & & .206 & .126 & .405 \\
\hline \multicolumn{5}{|c|}{$\begin{array}{l}\text { a. Test distribution is Normal. } \\
\text { b. Calculated from data }\end{array}$} \\
\hline Sumber: Perhitungan SP & S 21, 2016 & & & \\
\hline
\end{tabular}

Hasil uji normalitas pada tabel 5 menunjukkan menunjukkan bahwa nilai signifikasi untuk variabel stres kerja sebesar 0.126, kompensasi sebesar 0.405, dan kepuasan kerja sebesar 0.206, Berdasarkan hasil analisis uji normalitas dengan SPSS dapat dilihat bahwa dengan taraf uji sebesar 5\% $(\alpha=0.05)$ semua variabel memiliki P-value (sig.) di atas 0.05 sehingga dapat disimpulkan bahwa semua variabel yaitu stres kerja, kompensasi, dan kepuasan kerja berdistribusi normal sehingga memenuhi syarat dilakukan metode statistik parametrik analisis regresi linear berganda.

\section{Uji Linearitas}

Dalam melakukan uji linearitas, dua variabel dikatakan mempunyai hubungan yang linear bila signifikasi (linearity) kurang dari 0.05. Hasil uji linearitas dapat dilihat pada tabel 6 :

Tabel 6. Hasil Uji Linearitas

\begin{tabular}{cc}
\hline Variabel & NilaiSignifikansi \\
\hline Stres Kerja* Kepuasan Kerja & 0,000 \\
\hline Kompensasi* Kepuasan Kerja & 0,000 \\
\hline Sumber: Perhitungan SPSS 21,2016
\end{tabular}

Sumber: Perhitungan SPSS 21, 2016 
Dari Tabel 8, masing-masing variabel $\mathrm{X}$ memiliki nilai linearity yaitu variabel stres kerja $\left(\mathrm{X}_{1}\right)$ sebesar 0.000 dan variabel kompensasi $\left(\mathrm{X}_{2}\right)$ sebesar 0.000 sehingga dapat dikatakan bahwa setiap variabel $\mathrm{X}$ terdapat hubungan yang linier terhadap Y karena nilai Sig. Linearity $<0,05$.

\section{Uji Multikolinearitas}

Kriteria yang digunakan dalam uji multikolinearitas adalah jika besar VIF $<5$ atau mendekati, maka mencerminkan tidak terjadi multikolinieritas. Hasil uji multikoliniearitas dapat dilihat pada tabel 7 :

Tabel 7. Hasil Uji Multikolinearitas

\begin{tabular}{llrr}
\hline Model & & \multicolumn{2}{c}{ Collinearity Statistics } \\
\cline { 3 - 4 } & & Tolerance & VIF \\
\cline { 2 - 4 } 1 & Stres Kerja & .953 & 1.050 \\
\cline { 2 - 4 } & Kompensasi & .953 & 1.050 \\
\hline
\end{tabular}

Sumber: Perhitungan SPSS 21, 2016

Berdasarkan hasil uji multikolinearitas pada Tabel 7 dengan menggunakan statistik pengolahan data, diketahui angka VIF untuk variabel stres kerja sebesar 1.050 dan kompensasi sebesar 1,050. Nilai VIF dari seluruh variabel bebas adalah kurang dari 5, maka di antara kedua variabel bebas tersebut tidak ditemukan adanya masalah multikolinearitas.

\section{Uji Heteroskedastisitas}

Prasyarat yang harus terpenuhi dalam model regresi adalah tidak adanya masalah heteroskedastisitas. Jika signifikasi $<0.05$, maka terjadi masalah heteroskedastisitas. Hasil uji heteroskedastisitas dapat dilihat pada tabel 8 :

Tabel 8. Hasil Uji Heterokedastisitas

\begin{tabular}{|c|c|c|c|c|c|}
\hline \multicolumn{6}{|c|}{ Correlations } \\
\hline & & & $\begin{array}{c}\text { Unstandar } \\
\text { dized } \\
\text { Residual }\end{array}$ & $\begin{array}{l}\text { Stres kerja } \\
\qquad\left(\mathrm{X}_{1}\right)\end{array}$ & $\begin{array}{l}\text { Kompensasi } \\
\left(\mathrm{X}_{2}\right)\end{array}$ \\
\hline \multirow{7}{*}{ Spearman's rho } & \multirow{3}{*}{ Kepuasan Kerja } & $\begin{array}{l}\text { Correlation } \\
\text { Coefficient }\end{array}$ & 1.000 & -.007 & -.016 \\
\hline & & Sig. (2-tailed) & . & .951 & .895 \\
\hline & & $\mathrm{N}$ & 70 & 70 & 70 \\
\hline & \multirow{3}{*}{ Komitmen Organisasi } & $\begin{array}{l}\text { Correlation } \\
\text { Coefficient }\end{array}$ & -.007 & 1.000 & $.280^{\circ}$ \\
\hline & & Sig. (2-tailed) & .951 & . & .019 \\
\hline & & $\mathrm{N}$ & 70 & 70 & 70 \\
\hline & $\begin{array}{l}\text { Unstandardized } \\
\text { Residual }\end{array}$ & $\begin{array}{l}\text { Correlation } \\
\text { Coefficient }\end{array}$ & -.016 & $.280^{\circ}$ & 1.000 \\
\hline
\end{tabular}




\begin{tabular}{rrrrr}
\hline & Sig. (2-tailed) & .895 & .019 &. \\
\cline { 2 - 5 } & $\mathrm{N}$ & 70 & 70 & 70 \\
\hline
\end{tabular}

**. Correlation is significant at the 0.01 level (2-tailed).

Sumber: Perhitungan SPSS 21, 2016

Pada Tabel 8, diketahui korelasi antara stres kerja dengan unstandardized residual menghasilkan nilai signifikasi sebesar 0.951 dan korelasi antara kompensasi dengan unstandardized residual menghasilkan nilai 0.895. Jadi, dapat disimpulkan bahwa pada model regresi tidak ditemukan adanya masalah heteroskedastisitas, hal ini karena nilai signifikasi korelasi lebih besar dari 0.05.

\section{Uji Hipotesis}

\section{Hasil Persamaan Regresi Linear Berganda}

Untuk melihat persamaan regresi antara stres kerja dan kompensasi terhadap kepuasan kerja dapat dilihat pada tabel 9 :

Tabel 9. Hasil Persamaan Regresi Linier Berganda

\begin{tabular}{lccccc}
\hline Model & \multicolumn{7}{c}{ Unstandardized Coefficients } & $\begin{array}{c}\text { Standardized } \\
\text { Coefficients }\end{array}$ & $\mathrm{t}$ & Sig. \\
\cline { 2 - 5 } & $\mathrm{B}$ & Std. Error & Beta & \\
\hline (Constant) & 26,723 & 4,237 & & 6,306 &, 000 \\
\hline Stres Kerja $\left(\mathrm{X}_{1}\right)$ &,- 537 &, 110 &,- 458 & $-4,879$ &, 000 \\
\hline Kompensasi $\left(\mathrm{X}_{2}\right)$ &, 567 &, 138 &, 387 & 4,115 &, 000 \\
\hline
\end{tabular}

Sumber: Perhitungan SPSS 21, 2016

\section{Hipotesis 1}

\section{$\mathrm{H}_{0}$ : Stres Kerja tidak berpengaruh signifikan terhadap Kepuasan Kerja}

\section{Ha : Stres Kerja berpengaruh signifikan terhadap Kepuasan Kerja}

Berdasarkan tabel 9, dapat lihat bahwa variabel stres kerja memiliki nilai $t_{\text {hitung }}$ sebesar $-4,879$. Nilai $t_{\text {hitung }}$ kemudian dibandingkan dengan nilai $t_{\text {tabel }}$ yang dicari pada $\alpha=5 \%: 2=2,5 \%$ (uji 2 sisi) dengan derajat kebebasan (df) $n-k-1$ atau 70-2-1=67, dimana $\mathrm{n}$ adalah jumlah sampel dan $\mathrm{k}$ adalah jumlah variabel bebas. Berdasarkan perhitungan tersebut, didapat $t_{\text {tabel }}$ sebesar 1.996 dengan demikian $-\mathrm{t}_{\text {hitung }}<\mathrm{t}_{\text {tabel }}$ serta nilai signifikansi pada variabel stres kerja sebesar 0.000 , dengan demikian lebih kecil dari 0,05. Dapat diambil kesimpulan bahwa $\mathbf{H}_{\mathbf{0}}$ ditolak dan 
$\mathbf{H}_{\mathbf{a}}$ diterima. Dengan demikian stres kerja memiliki pengaruh yang signifikan terhadap kepuasan kerja.

Hal tersebut senada dengan penelitian terdahulu yang dilakukan oleh Ari Styawahyuni dan Made Yuniari (2013) yang berjudul "Pengaruh Pemberdayaan Karyawan dan Stres Kerja Terhadap Kepuasan Kerja Karyawan di kampoeng seafood jimbaran bay". Berdasarkan penelitian tersebut, didapatkan hasil penelitian bahwa stres kerja berpengaruh signifikan terhadap kepuasan kerja karyawan.

\section{Hipotesis 2}

\section{$\mathrm{H}_{0}$ : Kompensasi tidak berpengaruh signifikan terhadap Kepuasan Kerja}

\section{Ha : Kompensasi berpengaruh signifikan terhadap Kepuasan Kerja}

Selain itu tabel 9 juga menunjukkan nilai $t_{\text {hitung }}$ untuk variabel komitmen organisasi sebesar 4,115, serta nilai signifikansi sebesar 0.000. Hal tersebut menunjukkan bahwa $t_{\text {hitung }}>t_{\text {tabel }}$ dan nilai signifikansi lebih kecil dari 0.05 . Artinya, $\mathbf{H}_{\mathbf{0}}$ ditolak dan $\mathbf{H}_{\mathbf{a}}$ diterima. Dengan demikian, terdapat pengaruh yang signifikan antara kompensasi terhadap kepuasan kerja.

Hal tersebut senada dengan penelitian terdahulu yang dilakukan oleh Fauzan Muttaqqien (2014) yang berjudul "Pengaruh Kepemimpinan dan kompensasi terhadap Kepuasaan Kerja Karyawan Outsourcing pada PT. BRI persero, tbk cabang lumajang”. Berdasarkan hasil penelitian tersebut, dapat diketahui bahwa kompensasi memiliki pengaruh yang signifikan terhadap kepuasan kerja karyawan.

Berdasarkan tabel 9, dapat diperoleh persamaan regresi liniear berganda untuk hipotesis ketiga seperti berikut ini:

$$
Y^{\prime}=26,723-0.537 X_{1}+0.567 X_{2}
$$

Konstanta pada model persamaan tersebut sebesar 26,723, artinya tanpa adanya variabel independen, variabel kepuasan kerja sudah mencapai 26.723. Koefisien regresi variabel stres kerja $\left(\mathrm{X}_{1}\right)$ sebesar -0.537. Artinya, jika variabel stres kerja $\left(\mathrm{X}_{1}\right)$ ditingkatkan sebesar satu satuan dengan asumsi nilai variabel $\mathrm{X}_{2}$ tetap, maka variabel kepuasan kerja (Y) akan mengalami penurunan sebesar 0.537 dan stres kerja berpengaruh negatif terhadap kepuasan kerja. 
Koefisien regresi variabel kompensasi $\left(\mathrm{X}_{2}\right)$ sebesar 0,567. Artinya, jika variabel kompensasi $\left(\mathrm{X}_{2}\right)$ mengalami kenaikan satu satuan dengan asumsi nilai variabel $\mathrm{X}_{1}$ tetap, maka variabel kepuasan kerja (Y) akan mengalami peningkatan sebesar 0,567 dan kompensasi berpengaruh positif terhadap kepuasan kerja.

\section{Hasil Uji F}

Untuk menguji hipotesis ketiga, yaitu apakah terdapat pengaruh antara stres kerja dan kompensasi secara bersama-sama atau simultan terhadap kepuasan kerja, maka perlu dilakukan uji F. Hasil uji F dapat dilihat pada tabel 10 :

Tabel 10. Hasil Uji F

\begin{tabular}{llccccc}
\multicolumn{7}{c}{ ANOVA $^{\mathbf{a}}$} \\
\hline \multirow{2}{*}{1} & & Sum of Squares & Df & Mean Square & F & Sig. \\
\hline \multirow{2}{*}{1} & Regression & 846.667 & 2 & 423.334 & 25.966 & $.000^{\text {a }}$ \\
\cline { 2 - 7 } & Residual & 1092.319 & 67 & 16.303 & & \\
\cline { 2 - 7 } & Total & 1938.986 & 69 & & & \\
\hline
\end{tabular}

a. Dependent Variable: kepuasan kerja

b. Predictors: (Constant), Stres Kerja, Kompensasi

Sumber : Perhitungan SPSS 21, 2016

\section{Hipotesis 3}

$\mathrm{H}_{0}$ : Stres Kerja dan Kompensasi secara simultan tidak berpengaruh signifikan terhadap Kepuasan Kerja

\section{Ha : Stres Kerja dan Kompensasi secara simultan berpengaruh signifikan} terhadap Kepuasan Kerja

Pada tabel 10, F hitung yang diperoleh sebesar 25,966. Nilai $F_{\text {hitung kemudian }}$

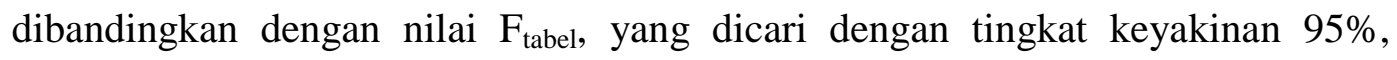
$\alpha=5 \%$ dengan df 1 (jumlah variabel-1) atau 3-1 = 2, dan df 2 (n-k-1) atau 70-21=67. Berdasarkan perhitungan tersebut, didapat $F_{\text {tabel }}$ sebesar 3,13 dengan demikian $F_{\text {hitung }}>F_{\text {tabel }}$. Signifikasi pada uji F sebesar 0.000; dengan demikian lebih kecil dari 0.05. Kesimpulan yang dapat diambil adalah variabel stres kerja dan kompensasi berpengaruh secara bersama-sama terhadap variabel kepuasan kerja.

Hal tersebut senada dengan penelitian terdahulu yang dilakukan oleh Rocky potale dan Yantje uhing (2015) yang berjudul "Pengaruh Kompensasi dan Stres Kerja terhadap Kepuasan Kerja Karyawan pada PT.Bank sulut cabang utama manado". Berdasarkan penelitian tersebut, dapat dihasilkan bahwa stres kerja dan 
kompensasi secara bersama-sama berpengaruh signifikan terhadap kepuasan kerja karyawan.

\section{Hasil Analisis Koefisien Determinasi}

Analisis determinasi diperlukan untuk mengetahui seberapa besar persentase pengaruh variabel independen yaitu stres kerja dan kompensasi terhadap variabel dependen yaitu kepuasan kerja. Hasil analisis determinasi dapat dilihat pada tabel 11 :

Tabel 11. Hasil Analisis Koefisien Determinasi Model Summary ${ }^{\text {b }}$

\begin{tabular}{ccccc}
\hline Model & $\mathrm{R}$ & $\mathrm{R}$ Square & Adjusted R Square & Std. Error of the Estimate \\
\hline 1 & $.661^{\mathrm{a}}$ & .437 & .420 & 4.038 \\
\hline
\end{tabular}

a. Predictors: (Constant), Stres Kerja, Kompensasi

b. Dependent Variable: Kepuasan Kerja Sumber: Perhitungan SPSS 21, 2016

Ditinjau dari tabel 11 dapat ditinjau bahwa nilai Adjusted $\mathrm{R}^{2}$ sebesar 0.420 atau $(42.0 \%)$. Hal ini menunjukkan bahwa $42.0 \%$ kepuasan kerja dijelaskan oleh faktor stres kerja dan kompensasi, sedangkan sisanya sebesar 58.0\% dipengaruhi atau dijelaskan oleh variabel lain diluar variabel yang dibahas dalam penelitian ini.

\section{KESIMPULAN, IMPLIKASI, DAN SARAN}

\section{Kesimpulan}

Berdasarkan hasil penelitian mengenai Pengaruh Stres Kerja dan Kompensasi terhadap Kepuasan Kerja Karyawan PT. Tri Megah Makmur, maka dapat diambil kesimpulan sebagai berikut:

1. Gambaran stres kerja, kompensasi dan kepuasan kerja karyawan PT. Tri Megah Makmur adalah :

a. Stres kerja yang dirasakan karyawan PT. Tri Megah Makmur tergolong Tinggi.

b. Kompensasi yang diberikan PT. Tri megah makmur tergolong rendah, bila dibandingkan dengan UMR yang ditentukan pemerintah DKI Jakarta. 
c. Kepuasan kerja karyawan PT. Tri Megah Makmur masih tergolong rendah, Berdasarkan hasil penelitian yang didapat, sebagian besar responden masih menunjukan kepuasan kerja yang rendah, diakibatkan dengan pendapatan yang didapat tidak sesuai yang diharapkan karyawan.

2. Terbukti secara empiris stres kerja memiliki pengaruh negatif dan signifikan terhadap kepuasan kerja karyawan PT. Tri Megah makmur.

3. Terbukti secara empiris kompensasi memiliki pengaruh positif dan signifikan terhadap kepuasan kerja karyawan PT. Tri Megah Makmur.

4. Terbukti secara empiris stres kerja dan kompensasi memiliki pengaruh secara simultan terhadap kepuasan kerja karyawan PT. Tri Megah Makmur.

\section{Implikasi}

Berdasarkan kesimpulan yang telah dikemukakan diatas, diketahui terdapat pengaruh negatif antara stres kerja terhadap kepuasan kerja, pengaruh positif antara kompensasi terhadap kepuasan kerja, serta stres kerja dan kompensasi secara bersama-sama mempengaruhi kepuasan kerja pada karyawan PT.Tri Megah Makmur. Hal ini menunjukkan bahwa stres kerja dan kompensasi memiliki peranan yang penting dalam menentukan peningkatan dan penurunan kepuasan kerja karyawan.

Implikasi dari studi penelitian ini adalah agar perusahaan dapat menurunkan stres kerja yang dialami karyawan dan meningkatkan kompensasi, agar kepuasan kerja karyawan dapat terus meningkat.

Namun tidak hanya stres kerja dan kompensasi saja yang dapat mempengaruhi kepuasan kerja karyawan karena masih banyak faktor lain yang mempengaruhinya. Namun penelitian ini telah dapat membuktikan secara empiris bahwa stres kerja dan kompensasi merupakan faktor yang dapat mempengaruhi kepuasan kerja karyawan.

\section{Saran}

\section{Saran yang ditujukan untuk PT. Tri Megah Makmur}

- perusahaan perlu melakukan pendekatan melalui supervisor terhadap karyawan yang memiliki kepribadian tertutup agar mau menceritakan masalah atau kendala 
yang dialaminya, kemudian memberikan solusi dan alternatif penyelesaian masalah sehingga permasalahan dapat terselesaikan dengan baik. lalu Perusahaan disarankan untuk menyesuaikan gaji pokok karyawan sesuai dengan UMR (Upah Minimum Regional) DKI jakarta dan sesuai dengan perusahaan yang sejenis. Kemudian perusahaan harus memberikan pengawasan terhadap karyawan yang sedang bekerja, agar karyawan bisa termotivasi dalam melakukan pekerjaannya, sehingga bisa menyelesaikan dengan baik.

\section{2. saran untuk penelitian lanjutan}

- Penelitian ini dapat dilakukan kembali dengan menambah variabel-variabel yang secara teori memungkinkan dapat mendukung variabel terikat kepuasan kerja antara lain: motivasi, work-life balance, pengembangan karir, gaya kepemimpinan, lingkungan kerja dan iklim organisasi. Penelitian ini juga dapat dilakukan kembali dengan menggunakan variabel yang sama namun objek penelitian yang berbeda atau menggunakan variabel yang berbeda dengan objek penelitian yang sama.

\section{DAFTAR PUSTAKA}

D.L, Nelson dan C, Quick J. 2006. Organizatonal Behavior Foundations Realities and Challenges(USA: Thompson South Western).

Dwi Rizkiyani dan Susanti R Saragih. 2012. "Stres Kerja dan Motivasi Kerja Pada Petugas Lembaga Pemasyarakatan”, Jurnal Manajemen, Vol.12, No.1.

Irwan Lukiyanto. 2014. "Pengaruh Kompensasi Finansial dan Stres Kerja Terhadap Kepuasan Kerja Karyawan”, Jurnal Ilmu Manajemen, Vol. 2, No. 1.

Jane Y.Rooboth. 2015. Analisis "Work Family Conflict, Stres Kerja Dan Kinerja Wanita Berperan Ganda Pada Yayasan Compassion East Indonesia", Jurnal Riset Bisnis dan Manajemen, Vol.3 ,No.1.

Mardahleni. 2013. "Pengaruh Kompensasi Terhadap Kepuasan Kerja Karyawan ( Biro Distribusi dan Transportasi ) pada PT. Semen Padang”, e-jurnal apresiasi ekonomi, Vol.1, No.1.

Muttaqien Fauzan. 2014. "Pengaruh Kepemimpinan dan Kompensasi Terhadap Kepuasan Kerja Karyawan Outsourching Pada PT.BRI persero tbk Cabang Lumajang", Jurnal WIGA, Vol. 4 No. 1. 
Jurnal Riset Manajemen Sains Indonesia (JRMSI) | Vol 7, No. 2, 2016

Potale, Rocky dan Uhing Yantje. 2015. "Pengaruh Kompensasi dan Stres Kerja Terhadap Kepuasan Kerja Karyawan Pada PT. Bank Sulut Cabang Utama Manado", Jurnal EMBA Vol.3 No.1.

Puspita Wulansari, Andre Harjana Damanik, dan Arif Partono Prasetio. 2014. "Pengaruh Kompensasi Terhadap Motivasi Karyawan di Departemen Sumber Daya Manusia Pln Kantor Distribusi Jawa Barat dan Banten”, Jurnal Manajemen Indonesia, Vol.14, No.2.

Priyatno, Dwi. 2010. Teknik Mudah dan Cepat Melakukan Analisis Data Penelitian dengan SPSS. Yogyakarta: Gaya Media.

Robbins, Stephen dan Timothy, Judge. 2009. Perilaku Organisasi, (Organizasional Behavior) (Jakarta: Salemba Empat).

Siagian, Sondang. 2005. Manajemen Stratejik, Edisi keenam (Jakarta : PT. Bumi Aksara)

Styawahyuni, Ari dan Yuniari Made. 2013. "Pengaruh Pemberdayaan Karyawan dan Stres Kerja Terhadap Kepuasan Kerja Karyawan Kampoeng Seafood Jimbaran Bay”, Jurnal Universitas Udayana Bali, Indonesia.

Sugiyono. 2008. Statistika Untuk Penelitian. Bandung: CV. Alfabeta. . 2011. Metode Penelitian Pendidikan Pendekatan Kuantitatif Kualitatif \& Research and Development. Bandung : Alfabeta.

Tunjungsari, Peni. 2011. "Pengaruh Stres Kerja Terhadap Kepuasan Kerja Karyawan pada Kantor Pusat PT. Pos Indonesia (PERSERO) Bandung", Vol. 1 No. 1.

Umar, Husein. 2008. "Metode Penelitian untuk Skripsi dan Tesis Bisnis Edisi Kedua”. (Jakarta: PT. Raja Grafindo Persada). 